\title{
Environmental Risk-Factors of Indiscriminate Refuse Disposal in Ekiti State, Nigeria
}

\author{
1 Isaac Olusola Akindutire (Ph.D), 2Eunice Oluyemisi Alebiosu \\ Department of Human Kinetics and health Education, Ekiti State University, Ado-Ekiti, Nigeria.
}

\begin{abstract}
One of the commonly accepted indicators for assessing the level of development of any nation is the efficient management of its refuse. Inefficient management of refuse poses great threats to public health in any environment. The indiscriminate dumping of refuse is unsightly, risky and exposes people to diseases. This paper examined the environmental risk-factors arising from indiscriminate disposal of refuse by residents of EkitiState. The paper also identified those risk-factors, such as water pollution, air pollution, flooding, environmental accidents, outbreak of diseases which can lead to health hazards ranging from mild ill-health to severe health calamities. Suggestions were made to help checkmate the risk-factors of indiscriminate disposal of refuse in Ekiti-State.
\end{abstract}

Keywords: Environment, Pollution, Refuse, Health hazard, Risk-factors

\section{Introduction:}

The term environment implies all the external factors, living and non-living materials which surround man. It does not only include water, air and soil but also social and economic conditions under which we live.

The key to man's health lies largely in his environment. A great deal of man's ill health can be traced to adverse environmental risk-factors such as water pollution, soil pollution, air pollution, poor housing conditions, presence of animal reservoirs and insect vectors of diseases which pose a constant threat to man's health. Often man is responsible for the environmental risk-factors in his environment through indiscriminate disposal of refuse.

Ekiti has been existing for long by its geographical location and victory in wars in the olden days. Ekiti, though a developing state, became prominent when it was carved out of Ondo-State as Ekiti-State in October 1996. The state has witnessed economic growth through various construction activities, establishment of commercial centres and small-scale industries, urbanization, increase in population and improvement in structural facilities for social services. The influx of people to the state resulted in rapid growth and expansion. There has also been daily increase in the heaps of refuse generated, littering the whole state. This has led to increase in environmental risk-factors which has resulted in the incidences of ill-health.

Refuses are rubbish or materials that are not needed and are economically unusable without further processing (Waste Management Information Link 2006). Olanipekun, Oyeniyi and Konwea asserted that refuse are unwanted, discarded, non-liquid materials emanating from various human activities at home, workshop, in the community and farms. Refuse and solid wastes include materials from house (paper, wood, dust, garbage) the street (paper, animal droppings, carcass, cellophane bags and leaves), market (empty sachets, bottles cartons etc) abandoned automobiles from industries, toxic industrial wastes, agricultural wastes and so on.

Indiscriminate disposal of refuse is a situation where refuse are dumped in any convenient place whether at home, school, street or market place not minding the environmental risk-factors that are likely to follow. Olokor (2001) discovered that the problem of indiscriminate disposal of refuse and unsanitary environment should be given urgent attention because of the risk-factors on human health. Such risk-factors range from ill-health to severe health calamities, such as outbreak of epidemic diseases with adverse effects in some cases. Ekpu and Archibong (2007) discovered that the high rate of refuse generation by people both in rural and urban areas is a direct reflection of the inefficient ways materials and energy resources are being used. Nearly every human activity creates refuse, which may be difficult to get rid of, especially with the careless attitude of many people to refuse disposal. Lucas and Gilles (2006) asserted that indiscriminate habit of refuse disposal has significantly affected environmental cleanliness and in turn bred environmental risk-factors affecting the health and well-being of people.

Achalu and Achalu (2004) stated that refuse refers to all the component parts of solid wastes found in the human environment; while Moronkola and Okanlawon (2003) stressed that solid wastes are unwanted, discarded, non-liquid materials emanating from various activities of man at home, school and workplace which may be combustible. Similarly Alakija (2002) regards refuse as discarded materials from houses, streets markets and industries. Refuse disposal is a process of collecting and discarding garbage and other waste materials while indiscriminate refuse disposal is a process of unhygienic practice of dumping waste in any convenient place 
whether at home, street, school or market place thereby producing devastating risk-factors to man and its environment

The environment comprises the land on which we cultivate and build, the water that we drink and use for irrigation, fishing, farming and navigation, the air that we breathe, and other living and non-living resources. The quality of the environment has been declining rapidly over the years as a result of environmental pollution. The cost/effect of environmental damage to man, which may be borne immediately or at some point in the future are principally losses in health, productivity and amenities, all which can affect human well-being. The well-being of a man depends on an environmental balance in land use between the urban areas and the agricultural and forest zones (Gleen2003).Anderson (2003) asserted that environmental risk-factors are not only a national concern, but are also a worldwide problem with grave implications for human survival. It was discovered that it has also constituted serious health threat in the past to man and its environment. Based on the background, this paper therefore, examines sources of refuse, the various risk factors of indiscriminate refuse disposal and the health implications of such unwholesome practices.

\section{Sources of Refuse:-}

The output of daily waste depends upon the dietary habits, life styles, living standards and the degree of urbanization and industrialization of people living in a community. Sources of refuse as identified by Park (2007) include:

1. Refuse collected by the street cleansing service or scavenging called street refuse which consists of leaves, straw paper, animal droppings and litter of all kinds.

2. Market refuse collected from markets which contains a large proportion of putrid vegetables and animal matters.

3. Stable litter collected from stables which contain mainly animal droppings and left-over animal feeds.

4. Industrial refuse comprises a wide variety of waste, ranging from completely inert materials, such as calcium carbonate, to highly toxic and explosive compounds.

5. Domestic refuse consists of ash, rubbish and garbage. Ash is the residue from fire used for cooking and heating. Rubbish comprises of paper, clothing, bits of wood, metal, glass, dust and dirt. Garbage is the waste material arising from the preparation, cooking and consumption of food. It consists of waste food, vegetable peelings and other organic matter.

\section{Methods of Refuse Disposal}

The correct disposal of waste is very important and many options are available depending on the types of wastes being produced, the volume of wastes being produced and the best disposal method to use. The principal disposal methods of refuse are:-

1. Controlled tipping or sanitary land-fill

2. Incineration or burning

3. Compositing

4. Dumping

5. Manure pits

6. Burial

These methods are discussed below

1. Controlled tipping or sanitary land-fill: sanitary land fill is the most satisfactory method of domestic waste disposal. It consists of four steps:

Depositing waste in a planned controlled manner

Spreading and compacting it in layers to reduce its volume

盺 Covering the material with a layer of earth

音 Compacting the earth cover

Landfill areas should be located on the periphery of the town. Care ias needed in the selection of landfill sites as domestic waste could be highly polluting. (Lucas and Gilles 2006).

2. Incineration or burning: burning is carried out where waste content is low and always at a localized level where there is no adequate collection services. Burning has a lot of disadvantages because of its close proximity to domestic dwelling. It could create fire risk in addition to producing atmospheric pollution.

3. Composting: it is best suited in situations where waste high in organic matter content is produced. Composting is a method of combined disposal of refuse and night soil or sludge.

4. Open Dumping or Indiscriminate Dumping: refuse is dumped in low lying areas as an easy method of disposal of dry refuse. The risk-factors of open dumping are:

the refuse is exposed to flies and rodents;

it serves as nuisance from the smell and unsightly appearance;. 
the loose refuse is dispersed by wind; and

drainage from dumps contributes to the pollution of surface and ground water;

This method is considered as a most unsanitary method that creates public health hazards, a nuisance and severe pollution of the environment (Park 2007).

5. Manure pits: this method of refuse disposal is effective and simple in rural communities. The problem of refuse disposal in rural areas can be solved by digging 'manure pits' by individual householders. The garbage, cattle dung, straw and leaves could be dumped into the manure pits and covered with earth after each day's dumping.

6. Burial: Nwankwo (2004) discovered that burial of refuse is a method suitable for small camps. A trench $1.5 \mathrm{~m}$ wide and $2 \mathrm{~m}$ deep is evacuated and after each day use, the refuse is covered with 20 to $30 \mathrm{~cm}$ of earth.

For the purpose of this paper, indiscriminate dumping of refuse would be considered, which is the throwing of refuse around resulting in gross pollution and the attendant risk-factors to human existence.

\section{Risk-factors of Indiscriminate Refuse Disposal}

Olokor (2001) asserted that the impact of indiscriminate disposal of refuse has been a worrisome health issue for quite sometime. One aspect of the problem is the fact that the cause-effect relationship takes a long time to establish in some cases while in other cases, the effects are seen immediately. The environmental riskfactors attached to indiscriminate refuse disposal can cause mild to moderate illness and at times severe illnesses that can lead to death. There could also be outbreak of diseases like cholera, typhoid fever, and other diseases, in severe forms causing death, especially in children ages $0-15$ years, whose immunity is not as strong as the adult population. Some risk-factors of indiscriminate refuse disposal include:

* Breeding of arthropod borne-diseases: Indiscriminate dumping of refuse promote the prolific breeding of arthropod-borne diseases like mosquitoes, houseflies, lice, tsetse flies, cockroaches which transmit diseases like malaria, viral encephalitis, typhoid, paratyphoid fever, diarrhea, dysentery, cholera, gastro-enteritis, amoebiasis, conjunctivitis, sleeping sickness, relapsing fever, scabies, filariasis, enteric pathogens etc. (Park 2007)

* Breeding of flies: the organic portion of solid waste ferments, giving rise to breeding of flies which can deposit infective materials on the skin or on food or other objects thereby contaminating it.Huge piles of refuse can constitute nuisance and unsightly scene especially when dumped in strategic places like motor parks, market places or on the streets causing offensive odour and health hazards. (Alakija 2002).

* Refuse dumps give rise to smug and air pollution when burnt openly. There is a risk-factor of air pollution in the event of accidental or spontaneous combustion of refuse. Air pollution signifies the presence in the atmosphere of substances generated by the activities of man that interfere with human health, safety or comfort. It is injurious to vegetation and animals and other environmental media, resulting in chemicals entering the food chain or being present in drinking water, causing health problems to man. Discharge of carbon monoxide by industries, domestic combustion of coal, wood or oil, open burning of refuse, incinerators, pesticide spraying, wind borne dust, fungi, moulds, bacteria and nuclear energy all contribute to air pollution (Ayodele 2007).

- Andrew (2007) noted that natural water sources provide convenient reservoir for disease agents, whether in their developmental or adult forms, human industrial activities heavily pollute available water sources due to noxious and hazardous chemicals as sullage from industries. There is possibility of water pollution if rain water passes through deposits of fermented refuse to contaminate underground water table through leakage or there is a more serious aspect of water pollution caused by human activity such as indiscriminate sewage and refuse disposal which contain decomposable organic matter and pathogenic organisms. Man's health could be adversely affected by the ingestion of contaminated water either directly or through food and by the use of contaminated water for purpose of personal hygiene leading to water-borne diseases like diarrhea and vomiting, hepatitis A, hepatitis E, poliomyelitis, typhoid and paratyphoid fever, bacillary dysentery, cholera, amoebiasis, worm infestations, schistosomiais and guineaworm or tape worm. (Park 2007).

- Indiscriminate dumping of refuse along streams and river courses can cause flooding thereby leading to natural disasters. A typical example was when flood carried away a young girl of seven years old in AdoEkiti that was sent to dump refuse on the drainage when rain was falling (Punch Feb 2013).

- Fire Disaster:-Unguarded burning of refuse or indiscriminate throwing of cigarette stubs into refuse dumps may cause fire disasters which can lead to serious devastating effect on human beings. Also fire may break out from the methane gas from the organic matter in refuse piles destroying lives and properties. (Lucas and Gilles 2006). 
Ayodele (2007) asserted that apart from the fact that disease agents in the air cause ill-health to man, air pollution by dust, smoke, other toxic substances and chemical vapours cause various forms of illness conditions and deaths. Indiscriminate disposal of house and industrial wastes are responsible for air pollution with toxic or hazardous substances. Through such pollution several people might be killed within few hours. Outbreak of infestations and communicable diseases like measles, chicken pox, diphtheria and pertussis are favoured through air-pollution as the diseases are air-borne in origin.

* Blockages in drainages and flooding: Achalu and Achalu (2004) discovered that indiscriminate dumping of refuse hinders free flow of erosion and floods when it rains causing blockage of drainages, diversion of flood to various places like living houses, farm lands leading to over-flooding, which results in destruction of lives and properties. Refuse dump along streams and river courses cause flooding which can result in natural disasters. It can also result in outbreak of diseases and plagues. Many people were killed due to flood in the Northern and Easter parts of Nigeria in 2012 and many properties were lost to flood including farm lands, schools and industries, leading to famine and draught.

- Environmental hazards/degradation: Moronkola (2003) claimed that indiscriminate dumping of refuse will give rise to offensive odour which is a source of nuisance to human existence as excessive intake of this polluted air can lead to choking of the lungs and breathing difficulty. People who are asthmatic patients can also react to the offensive odour by suffering from asthmatic attacks; death can also result if any of the breathing problems is not promptly managed. Accumulated refuse gives rise to noxious and offensive odour as a result of Ammonia $\left(\mathrm{NH}_{3}\right)$, Hydrogen Sulphide $\left(\mathrm{H}_{2} \mathrm{~S}\right)$, and amines that are produced when organic wastes are decomposed.

* Environmental accidents: Ajayi (2004) asserted that if an environment is polluted with filthy things like broken bottles, heaps of hazardous things, children and adults could receive injuries from the materials and if not quickly attended to, can lead to tetanus infection, which in turn, can kill the host. Heaps of refuse along motor parks or motor pathways can lead to road traffic accidents which could destroy lives and properties especially, when driving in the night and the driver is not aware of the heaps of refuse ahead.

* Spread of water-borne diseases: Indiscriminate disposal of refuse can give rise to spread of water-borne diseases like cholera, typhoid fever, diarrhoea, poliomyelitis, worm infestations and onchocerciasis and hepatitis which has continued to be a major public health problem in Ekiti-State. There appears to be an epidemic of typhoid and cholera in many communities in Nigeria now. Careful observations show that too many septic tanks are close to major sources of water, such as wells and boreholes. Refuse dumping sites are also close to streams and rivers that are being employed for domestic use like cooking, washing and drinking. If this unhealthy trend is not checked, the risk-factors of indiscriminate disposal of refuse may continue to increase. (Ajayi, 2004).

- Unsound Environmental Sanitation: According to Nwankwo (2004) indiscriminate disposal of refuse can constitute serious threat to human health and the achievement of sound environmental sanitation. Briggs (2000) submitted that refuse dumpsites are converted to urinals and defecation sites by the destitute, invaded by scavengers and animals, and served as breeding ground for disease vectors (flies, rodents, etc). Also accumulated garbage and rubbish become eyesore in the community and pollute the air, and act as breeding grounds for mosquitoes and other harmful insects. They also encourage street flooding.

* Epidemic Outbreak: Bassis (2004) claimed that serious and devastating outbreak of diseases and epidemics had been recorded owing to indiscriminate dumping of refuse. Such diseases include, cholera, typhoid and paratyphoid fever, diarrhea and vomiting leading to serious health implications, unnecessary and unavoidable spending and in some cases, death of the victims.

Indiscriminate disposal of refuse of any kind can lead to spread of diseases. Indiscriminate defecation may affect drinking water, which can cause sporadic outbreaks of diseases such as poliomyelitis and typhoid fever among others leading to permanent deformities of the victim and in some cases death. According to (Herbeth 2000) poor handling of refuse can cause illness especially when excreta contaminate the refuse and source of drinking water.

* National Depravity/Effects on the Nation: Accumulated garbage and rubbish become eyesore in the community and pollute the air, acting as breeding grounds for mosquitoes and other harmful insects especially where a foreigner has to be welcomed to the nation with huge accumulation of refuse. WHO (1997) revealed that as many as 2 million children die each year from diseases caused by indiscriminate disposal of waste.

* The public health concern and the concern of health educators by the occurrence of these risk-factors, especially in their severe forms, cannot be compared to the health benefits that would follow if the masses 
and government would face the environmental risk-factors squarely to eliminate the causative-agent which is indiscriminate disposal of refuse in the society Ouwamanam, Olusesi and Babatunde (2007).

\section{Conclusion}

1) It is so obvious that people in Ekiti State usually dump their refuse indiscriminately on the street and in the drainages. Indiscriminate dumping of refuse is a common phenomenon and the state of environmental health seems to be poor in Ekiti State, though the government is making some efforts, but much could still be done to reduce the risk-factors of indiscriminate disposal of refuse. This conclusion has been arrived at because open drains are almost everywhere with offensive odour, and little or no effort is being made to address the issue. Air pollution and water borne-diseases are also very common.

2) As a result of the observed dumping of refuse indiscriminately, a number of risk factors or health hazards had been identified.

\section{Recommendations}

Based on this conclusion, the following suggestions are hereby put forward:

1) Every household should obtain waste disposal baskets for refuse collection and dump inside strategically placed waste disposal containers provided by the government that would be emptied regularly.

2) The government should ensure that toilet facilities are provided everywhere especially in the market places and well supervised by sanitary health inspectors to ensure effective use.

3) The street cleaners employed by the ministry of environment should not be localized in the state capital alone but should be spread throughout all the nooks and crannies of the state to ensure cleanliness of the whole state.

4) Each local government area should also employ street cleaners under the supervision of local government Environment Health Officers to ensure down the drain cleanliness of the whole state.

5) The monthly environmental sanitation observed between 7.00-10.00am of the last Saturday of the month should be enforced both in the offices as it normally occurs every last Thursday of the month, in the market places and in every local government area to ensure compliance while defaulters should be severely dealt with.

6) There should be adequate provision of refuse vans and heavy machines for transportation of wastes for land filling purposes.

7) As a result of the problem of contamination by sewage effluent, regular and continuous bacteriological testing of public water supply must be carried out to determine the type and number of bacteria present and ensure the water is safe for use.

8) Sewage must be treated and must not be discharged into streams, rivers and lakes.

9) There is the need for the Federal government of Nigeria to address the problem of water pollution as this is the first step in reversing environmental degradation.

10) There should be effective public health education campaigns in the state and local governments on how to keep the environment free from indiscriminate disposal of refuse and its effects.

11) Waste recycling should be embraced by industries because, the waste of one industry could be used as raw materials for another industry: an example is waste cartons from breweries and pharmaceutical stores, which are indiscriminately dumped, could be converted to egg trays for poultry farmers.

12) An intervention strategy should be developed to help people cultivate environmental-friendly behaviour, through mass media campaigns, seminars, market approach, community groups and so on.

13) Policies aimed at keeping the environment clean should be formulated and enforced by appropriate authorities.

14) State and local government authorities should use environmental health officers and sanitary inspectorate division of ministry of environment to supervise refuse disposal in the community.

15) Awareness campaigns on the health implication of environmental risk-factors should be intensified to educate the masses.

16) Environmental-friendly refuse disposal methods such as burying or incineration should be adopted in the place of indiscriminate dumping of refuse.

17) There is need to discard the open dumping method and review the sanitary land fills method, which is considered safe, cheap and effective when properly planned and executed.

\section{References}

1] Achalu O.E and Achalu E.I (2004) Environmental Health and Pollution Control.LagosSimarch

2] Ajayi F.T. (2004) A Guide to Primary Health Care Practice in Developing Countries, Government Printer; Ekiti-State.

3] Alakija W (2002). Essentials of Community Health: Primary Health Care and Management. BeninAmbik Press.

4] Anderson C.L.(2003) Community Health St. Louis C-V Mosby Company. 
5] Andrew I.O (2007) Water Pollution in Nigeria: Concepts, Causes and HealthImplicationsNigerianSchool Health Journal 19 (2) 38 43

6] Ayodele-Oni S. (2007) Environmental Health Education in Schools and In the Community.NigerianSchool Health Journal 19(2) 116-122

7] BassisL.(2004)Wastedisposalwww.unich.edui/gs/265/society/wastedisposal/htm

8] Briggs J.A. (2000) Issues in Health Education Port-HarcoutMinson Publishers

9] Ekpuand Archibong M. (2007). Refuse Disposal Methods and Participation among Residents in Ikot Ekpene Local Government Area of AkwaIbom State, Nigeria. NigerianSchool Health Journal.

10] Gleen C. (2003) Healthful Living in the Environment St. Louis C-V Mosby Company.

11] HerbethJ. (2000) Environmental Pollution: www.environmentalexpert.com.

12] Kicon (2006) Hazardous Waste Transportation www.kicon.com/nhien/Bras/htm

13] Lucas O.A. and Gilles H.M. (2006).A Short Textbook of Public Health Medicine for the Tropics.New York

14] Moronkola O.A. and Okonlawon F.A (2003). Fundamentals of Public and Community Health Education: Ibadan; Royal People (Nigeria) Ltd.

15] Nwankwo B.O (2004) Environmental Sanitation and Health Owerri Colon Concepts.

16] Ogundele B.O. and Olubode O.O. (2007) Waste Generation and Management Practices of Industrial Establishments as Correlates of Health Stats of $\quad$ People of Ibadan; Nigeria. NigerianSchool Health Journal 19(1) 9-18

17] Okafor J.O. (2002) Principles of Healthful Living, Onitsha: Erudite Publishers EntNigeria

18] Olanipekun J.A, Oyeniyi P. and Konwea P.E. (2007).Assessment of Solid Waste Management Techniques in EkitiState Urban Area.NigerianSchool Health Journal 19(2) 75-82

19] Olokor C.O (2001) Hazardous Wastes: its production, effects, disposal and control in Nigeria Industries; Oyo: JONAPHER-SD 2(2) $258-267$

20] Ouwamanam M. Ac, Olusesi O.O and Babatunde S.O. (2007) Investigations into causes, Effects and Control of Environmental Pollution in Amuwo-Odofin Local Government Area of Lagos State.NigeriaSchool Health Journal 19(1) 71 -79.

21] Park K. (2007). Park's Textbook of Preventive and Social Medicine India; Banarsida Bhanot Publishers. 